Dialectic Volume I, Issue I: Critical Book Reviews

\title{
Are We There Yet?
}

\section{Insights on How to Lead by Design}

Written by Sam Bucolo

REVIEW BY HEATHER CORCORAN ${ }^{1}$

1. Director, College \& Graduate School of Art, Jane Reuter Hitzeman \& Herbert F. Hitzeman, Jr. Professor of Art, Sam Fox School of Design and Visual Arts, Washington University in

St. Louis, St. Louis, MO, USA

SUGgested CitATION: Pretty, A. “'Are We There Yet?' Insights on How to Lead by Design.” Review of “Are We There Yet” Insights on How to Lead by Design, written by Sam Bucolo. Dialectic, 1.1 (2016): pgs. 189-191. DOI: http://dx.doi.org/10.3998/dialec-

tic.14932326.0001.113 


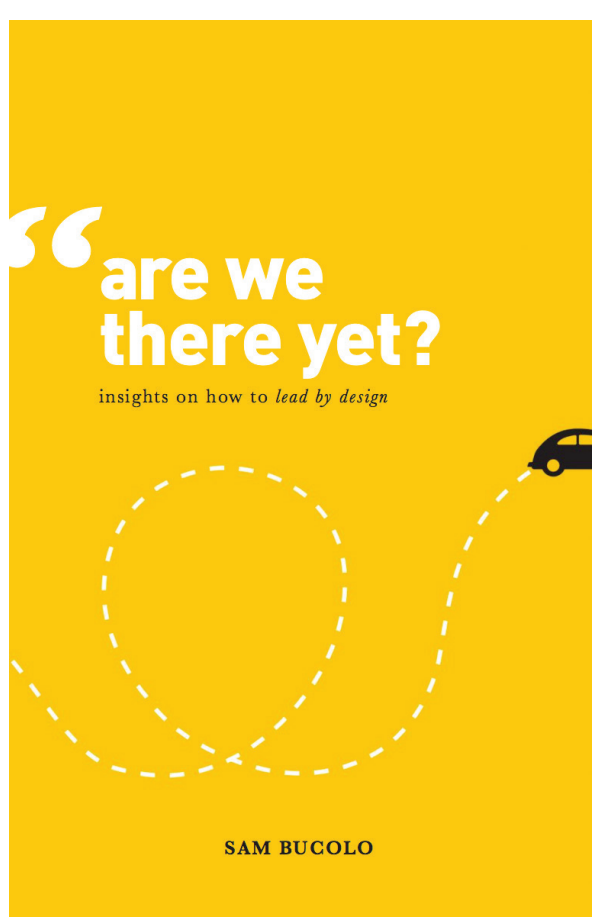

ABOVE: Book cover "Are We There Yet? Insights on How to Lead by Design”, by Sam Bucolo.

\section{"Are We There Yer? Insights on How to Lead by Design"}

Written by Sam Bucolo

REVIEW BY HEATHER CORCORAN

Washington University at St. Louis

In "Are We There Yet? Insights on How to Lead by Design," Sam Bucolo posits design process as a transformative agent for mid-sized businesses to become innovators. As a consultant to SMEs (small- to medium-sized enterprises, as he describes them), Bucolo documents his own experiences advocating for companies to understand their customers more deeply and systematically in order to reimagine business products, practices, and culture. He believes that midsized companies are ideally suited to engage design process, as they are small enough to have connections across all parts of the organization, and the potential for close contact with customers. Small and medium-sized businesses are also an economic powerhouse-comprising the largest employer category in the world's economy.

This book presents a framework for applying design process to business, and describes how design has affected a set of companies in Australia. It is a relevant read for design educators interested in design process as a tool of innovation, as well as the surrounding discourse about design thinking. It is also appropriate for design students who may find themselves challenged by employers to apply their knowledge of design to innovation-seeking business practices.

To be clear, the book is written to business leaders. Bucolo speaks to them in a direct, informal style. Chapter 1 is entitled "can you tell me how innovative you are?" "You" is a person in business. The book concludes with a series of questions for CEOs to consider. Each chapter ends with reflections for decision-makers in business. A bright yellow book, peppered with abstracted, iconic illustrations and design process and structure diagrams, Are We There Yet? reads as a guidebook-a kind of conversation between Sam Bucolo and businesses who seek innovation. Designers, design educators, and students of design who read the book will witness a dialogue. They have a tool to imagine how design practice and design education should evolve, though the book does not address the role that they might play explicitly.

Bucolo argues that three questions should drive a company's self-assessment of potential for innovation. First and foremost is the idea of customer: Who is your customer and what problem are you solving for them? The second question is about how the customer's priorities impact the daily operations of a business: What business activities accoss the organization do you carry out on a daity basis which ensure you'se addressing yous customer's problems? And the last question addresses building capacity and focus: What could you do less of that does not directly addsess yous custom. er's problem? These questions loosely correlate to the three elements of 
design led innovation (DLI) that he views as critical-customer value, strategic alignment, and management mindset.

Examples of consulting projects conducted by Bucolo include Centor, a company that produces door components. Through a DLI process, with over 300 interviews with employees, Centor learned that it would join a bigger, more diverse and profit-bearing market if it began to manufacture doors and windows, instead of just components, where it would able to differentiate its brand and product more directly. Without the design process, Centor likely would have continued to grow modestly inside the components market. And then there is the case of Gourmet Garden, a fresh herbs company. Seeking more innovation from its tubed herbs product, it conducted observations of professional chefs and ordinary families, with assessments of shopping trips and everyday refrigerators. Gourmet Garden learned that they needed to refine the way that they combined convenience and freshness in their herbs. Their primary consumer is a person for whom cooking dinner is a time challenge, and freshness a top priority. Their "lightly dried" herbs-an idea they developed and tested as a prototypewas not viewed as fresh enough. As a result, they developed a new package which made fresh herbs easier to access, as well as a set of bowls for herbs, both of which were met with market success.

Bucolo's endorsement of design process is strengthened by several references to design literature. He links the open-ended brainstorming of design thinking to abductive reasoning, a concept introduced by early 20th century philosopher Charles Sanders Peirce. Bucolo sees Peirce's work as a precursor to Nigel Cross' description of the problem-solution loop that happens in design process, as solutions sometimes refine-and even redefine-problems. He categorizes levels of innovation impact according to a revised version of the Danish Design Ladder. He describes Doblin's Ten Types of Innovation, which are aspects of a business that can be innovative; these are grouped under the three categories-configuration, offering, experience.

While the book's content is communicated mostly through text, there are several structure and process diagrams that shape Bucolo's framework, including what he terms the "Design Led Innovation Matrix" and the "Deep Dive Framework." The "Design Led Innovation Matrix" is a four part-process, organized according to individual and company-wide growth, and tactical and competitive strategy. The steps, which describe a company's typical path toward full engagement with design process, include awareness, experimentation/prototyping, transformation reorganizing, and education capability. The deep dive framework is used in parallel to help companies to assess themselves in a customer-driven way.

"Are We There Yet?" provides a model for how small-and middle-sized businesses can use design process to innovate. While it is a book written for business, it also participates in the emerging design discourse, which values the application of a design process to complex problems (e.g., wicked problems, business challenges, collaborative research issues), which may or may not require artifact-based solutions. This book provides valuable on-the-ground knowledge and experience for business, and an important context for designers, educators, and students. 